\title{
The analysis of a battery of motor tests as a predictor of future athletic performance in children of athletic school sport classes
}

\author{
Vítězslav Prukner* and Dagmar Sigmundová \\ Faculty of Physical Culture, Palacký University, Olomouc, Czech Republic
}

Copyright: (C) 2014 V. Prukner and D. Sigmundová. This is an open access article licensed under the Creative Commons Attribution License (http://creativecommons.org/licenses/by/4.0/).

Background: The prediction of future sport performance belongs among the most difficult tasks when choosing new talents. A great amount of attention is paid to designing a suitable battery of tests applicable to sport talent selections. Objective: The aim of this study is to analyse a battery of motor tests to assess the development of sports talents in athletic sport classes in order to suggest a battery of tests which will be able to produce an accurate assessment. Methods: The research was carried out among athletic classes in the years 2000-2007. As part of the study, 197 sixth grade students were monitored longitudinally through their ninth grade of elementary school. An entry measurement of motor skills was conducted with sixth grade students. The outgoing measurement, collected at the end of the students' ninth grade of elementary school, was in the form of four selected athletic disciplines. Results: The strongest association with overall results of athletic polyathlon was found in the standing long-jump, the 12 minute run, throwing a medicine ball and a $30 \mathrm{~m}$ cursory run. In boys, future performance in the athletic polyathlon can be predicted using $30 \mathrm{~m}$ cursory run, throwing a medicine ball, and a 12 minute run. In girls, performance in the athletic polyathlon can be predicted using $30 \mathrm{~m}$ cursory run and hexajump. Conclusions: An accurate prediction of future athletic performance can be made using a limited test battery which consists of, at most, three motor tests. This process efficiency can improve and economise efforts to identify talents.

Keywords: validity, talent identification, prediction, children, longitudinal study

\section{Introduction}

At most basic levels, talent refers to the quality identified at an earlier time that promotes exceptionality at a future time. Talent may refer to the presence or absence of specific genetic markers, which are important for success (Baker, Cobley, \& Schorer, 2011).

The basic factors of sport performance include the following: techniques, mental conditions, tactics, fitness, general preconditions, and external conditions. The structural components of sport performance, significant variables and bases of sports performance are called factors. Factors form an independent part of sport performance and are based on somatic, fitness, technical, tactical and mental bases of performance (Grosser, 1991).

Other authors address the key structural factors of sport performance in a similar way. For specification purposes, somatic factors are divided into

\footnotetext{
* Address for correspondence: Vítězslav Prukner, Department of Sport, Faculty of Physical Culture, Palacký University, tř. Míru 115, 77111 Olomouc, Czech Republic. E-mail: vitezslav.prukner@upol.cz
}

somatometric and somatotypological. Physiological factors are defined by the CNS, cardio-vascular, respiratory and energy systems, whereas mental factors are defined by personality and temperamental qualities, a significant role is played by motivation and mental resistance. Other significant factors include motor factors divided into fitness skills and motor skills (Dovalil, 2009).

As early as 1985 , motor performance was defined as physical preconditions $(\mathrm{P})$, motivation $(\mathrm{M})$ and intervening variables (I) that can be expressed using the following equation: $\mathrm{V}=\mathrm{f}(\mathrm{P}, \mathrm{M}, \mathrm{I})$, where the decisive aspect are motor preconditions, especially motor skills and motor capabilities (Měkota, 1985).

Talent is generally understood as a distinct demonstration of individual dispositions toward a particular specialized activity (Bunc, 2004). Among the determinants of athletic performance, we find - aerobic capacity, economy of movement, strength of muscular fibres, torso length and the limb length (Bunc, 2004; Grosser, 1991; Sultana, 2013).

According to Perič (2006) and Brown (2001), we are able to describe the base of performance as well 
as the variables which influence it and are easily definable e.g., sprint abilities, speed abilities, etc. In order to create a valid model we typically used common regressive equations. The prediction of sports performance is the most difficult aspect of the whole process. As such, there has been a great deal of attention devoted to searching for suitable test batteries applicable to sporting youths which would allow for the prediction of performance in certain areas and thus make the process of identifying talents more efficient. The efficacy of such a battery is provided primarily through individual development. The younger the observed participant, the more difficult it is to determine with any confidence his or her future performance (Blahuš, 1991; Bunc, 2004). To predict future performance, we must first determine the validity of the prediction in a given criterion, which we establish as the basis of a test.

An extensive method of searching for talent is based on the principal of a normal data distribution, where approximately $3 \%$ of individuals in a given population show a predisposition toward sport activities, as accomplished within a respective sport's performance. A newer method of identifying talent based on scientific evidence (Bunc, 2004). Researchers (Perič, 2008; Vala, Valová, Litschmannová, \& Klimtová, 2010) have described this method as creating a foundation of select individuals who are very likely to exhibit top performance. A disadvantage is the significant requirements placed upon the credibility of the selection criteria - the concepts of prediction validity and test reliability. The prediction and stability are dependent upon each other, as we cannot make predictive evaluations without stable indicators (Blahuš, 1991). The unique requirements of each sport demand for sport specific models or tests (Brown, 2001; Falk, Lidor, Lander, \& Lang, 2004; Kutlu, Yapıc1, Yoncalık, \& Çelik, 2012; Vaeyens, Lenoir, Williams, \& Philippaerts, 2008).

To mitigate the difficulties encountered in attempting to predict sports performance, a great amount of attention is paid to devising a suitable battery of tests applicable to the sport preparation of youths - one which allows the predicting of performance in certain areas and thus makes it more effective. The usability of this battery is subsequently improved through an ongoing development process.

Test batteries typically used to identify talented youths consist primarily of a set of items meant to assess the level of motor abilities and motor skills. A part of the test battery often also results in certain somatic measurements. Test batteries are time consuming to administer and require the involvement of both large groups of personnel as well as a range of diagnostic tools. To carry out all items in a test battery is thus often unnecessarily costly. The question then becomes whether all items are necessary, and whether there might be a simpler test battery which could replace the time and economically-demanding testing currently in use while still providing accurate results in predicting prospective sports performance. The authors' aim is to identify key test items in the test battery traditionally used to identify young athletes for participation in athletic sport classes at the Z $\check{S}$ Englišova elementary school, in Opava, Czech Republic, with a focus on simplifying the selection process of young adults.

\section{Aims}

The aim of the study was to analyse a battery of motor tests for a prediction of future athletic performance in athletic school sport classes.

Further goals:

- to assess the predictive validity of the results of entry motor tests in relation to the summary of results from the athletic polyathlon;

- to identify those tests in the test batteries which are key and necessary for the accurate prediction of future athletic performance;

- to suggest a structure of test battery relevant to the goals of identification and which accounts for both the necessary level of sport performance and the economic aspects of the identification process - the time demands of the selection process, the renting of facilities, the personnel and equipment requirements, etc.

\section{Methods}

\section{Ethics}

The current study was undertaken in the Czech Republic after receiving approval from the Institutional Research Ethics Committee at Faculty of Physical Culture, Palacký University.

Participation was voluntary and participants received no compensation. Data were anonymous and confidential and data protection measures were observed at all times. Legal representatives agreed to the inclusion of their child in the research.

\section{Participants}

The research took place at an elementary school in Opava during the period 2000-2007. The selection of the school was intentional, owing to its sport orientation. In order to participate in the research, all 197 sixth grade pupils agreed to be monitored longitudinally through their ninth grade of elementary school. Due to incomplete or missing data - i.e., in cases where 
the participant did not complete the entire testing process, or did not participate in the athletic polyathlon - 21 students' data were excluded. In total, 109 boys and 67 girls were analysed (Table 1).

Table 1

The mean and SD of body height and weight of boys and girls

\begin{tabular}{llrrrrr}
\hline & & \multicolumn{2}{c}{ Boys } & & \multicolumn{2}{c}{ Girls } \\
\cline { 3 - 4 } \cline { 6 - 7 } Grade & Variable & \multicolumn{1}{c}{$M$} & $S D$ & & \multicolumn{1}{c}{$M$} & $S D$ \\
\hline 6th & Height & 145.6 & 6.02 & & 141.9 & 5.98 \\
& Weight & 37.5 & 8.08 & & 34.5 & 6.48 \\
\multirow{2}{*}{9 th } & Height & 177.2 & 7.11 & & 166.6 & 6.12 \\
& Weight & 67.6 & 9.01 & & 58.1 & 6.49 \\
\hline
\end{tabular}

\section{Procedures}

The entry measurements of motor tests were conducted with sixth grade students. The outgoing measurement of the same sample consisted of four selected athletic disciplines which were carried out at the end of the ninth grade of elementary school (Figure 1). The selection of appropriate disciplines was done according to the most frequent occurrence in athletic competitions in the categories of younger and older pupils and according to the physical abilities called upon in specific motor tests.

Applied field tests of physical fitness:

1. $30 \mathrm{~m}$ cursory run (run for $30 \mathrm{~m}$ with a flying start) - after a short start $(20 \mathrm{~m})$, students run through

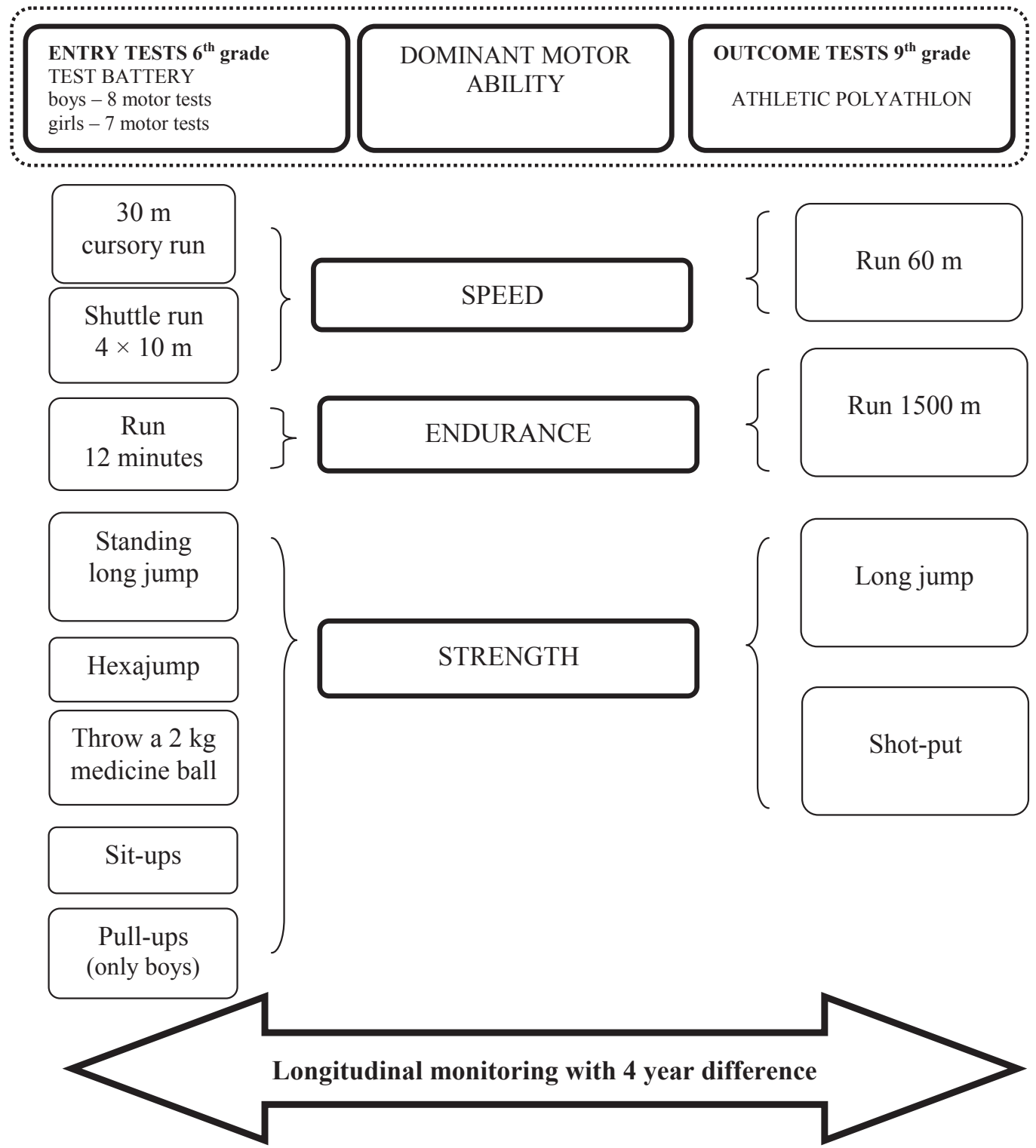

Figure 1. The scheme of research, entry and outgoing motor tests used in longitudinal monitoring 
2 photocells which provide an electronic measurement of their time accurate to within $0.01 \mathrm{~s}$.

2. Shuttle run - the goal is to run the four fastest $10 \mathrm{~m}$ tracks, which are defined by cones. The person runs around the cones twice and touches them twice. The test is measured to within $0.01 \mathrm{~s}$.

3. Run for 12 minutes (Cooper Test) - the goal is to cover as much distance as possible in 12 minutes. The test is conducted on an athletic track with the distance run measured to within $10 \mathrm{~m}$.

4. Standing long jump - from a standing position with legs slightly apart, students jump as far as possible. The test is measured to within $1 \mathrm{~cm}$.

5. Hexajump - from a spot, with a bounce from one leg and landing on the other, students complete 6 sequential jumps with the goal of covering as much distance as is possible, landing the last jump in a squat with their legs slightly apart. The distance covered is measured to within $5 \mathrm{~cm}$.

6. Throw a $2 \mathrm{~kg}$ medicine ball - from a standing position with legs apart facing the direction of the throw, students throw a $2 \mathrm{~kg}$ medicine ball with both hands as far as possible. The test is measured to within $5 \mathrm{~cm}$.

7. Sit-ups, 2 minutes - complete as many sit-ups as possible in 2 minutes.

8. Pull-ups with upper grip (boys only) - complete as many pull-ups as possible.

Athletic disciplines:

1. Run for $60 \mathrm{~m}$ - according to athletic rules.

2. Run for $1500 \mathrm{~m}$ - according to athletic rules.

3. Long jump - according to athletic rules.

4. Shot-put - according to athletic rules.

5. Athletic polyathlon (tetrathlon) - the sum of T-score in the disciplines of the athletic polyathlon (run for $60 \mathrm{~m}$, run for $1500 \mathrm{~m}$, long jump, shot-put).

\section{Statistical analysis}

Statistical analysis was undertaken using SPSS (version 19; IBM Corp., Armonk, NY, USA). In order to estimate predictive validity, the multiple correlation coefficient $R$ was applied. In order to predict athletic performance, stepwise regression analysis was conducted with a dependent variable - the result of the athletic polyathlon in the ninth grade, and independent variables - the items in the test battery completed at the beginning of the sixth grade of elementary school. Four years elapsed between the entry and the outgoing testing. An alpha level of .05 was set to evaluate statistical significance. For the assessment of the significance and appropriateness of the tests included in the selected test battery, the results of stepwise regression analysis of the whole motor test battery are essential.
The selection of a set of the best variables can be done using the gradual regression method. According to previous papers (Hebák \& Hustopecký, 1987; Loužecký, 1990) the following steps are performed:

1. The variable with the highest value of simple correlation coefficient is selected first;

2. It is determined which other variable increases the theoretical sum of squares the most and whether this increase is statistically significant for the selected $\alpha$;

3. The effect of a previously selected variable is analysed in case the variable was selected as the second (in reverse order);

4. This procedure is repeated until the increase caused by another variable is no longer statistically significant. Using the F-test, possible exclusion of previously selected variables is considered at each step;

\section{Results}

The analysis presented in this paper draws upon data collected from all 176 participants. The results in the entrance motor tests, boys and girls of grade 6 are presented in Table 2. The results of the final tests (grade 9) are presented in Table 3 . The total average performance in athletic polyathlon of boys and girls recalculated to T-score was an expected value of 200 (50 T-scores for each discipline).

The predictive validity of the total score of entry tests with regard to the results in the athletic polyathlon among boys was $r=.585$ ( $p<.01$ ) (Table 4$)$. The individual items of the test battery, excluding sit-ups, correlate significantly with the results of the athletic polyathlon. The most significant association with the overall results of the athletic polyathlon are to be found with the standing long-jump, the timed run for 12 minutes, the throwing of a $2 \mathrm{~kg}$ medicine ball (positive association) and the $30 \mathrm{~m}$ cursory run (negative association).

Table 5 shows that, among boys, future athletic performance can be predicted using the following tests - $30 \mathrm{~m}$ cursory run, throw a $2 \mathrm{~kg}$ medicine ball, and run 12 minutes.

Regression equation for polyathlon (in T-score) $=\mathrm{Y}$

Boys: $\mathrm{Y}_{\text {boys }}=-35.46 \cdot \mathrm{X}_{1}+11.26 \cdot \mathrm{X}_{2}+0.04 \cdot \mathrm{X}_{3}+178.64$ $\mathrm{X}_{1}=$ performance in $30 \mathrm{~m}$ cursory run test (s), $X_{2}=2 \mathrm{~kg}$ medicine ball throw $(\mathrm{m}), \mathrm{X}_{3}=12$ minute run (m)

Girls: $Y_{\text {girls }}=-76.17 \cdot X_{1}+8.69 \cdot X_{2}+397.64$

$\mathrm{X}_{1}=$ performance in $30 \mathrm{~m}$ cursory run test (s), $\mathrm{X}_{2}=$ hexajump $(\mathrm{m})$ 
Table 2

The results of entrance motor tests of boys and girls - grade 6

\begin{tabular}{lrrrrr}
\hline & \multicolumn{2}{c}{ Boys } & & \multicolumn{2}{c}{ Girls } \\
\cline { 2 - 3 } \cline { 5 - 6 } Test & \multicolumn{1}{c}{$M$} & \multicolumn{1}{c}{$S D$} & & \multicolumn{1}{c}{$M$} & \multicolumn{1}{c}{$S D$} \\
\hline Run for 12 minutes (m) & 2694.69 & 205.91 & & 2519.59 & 179.53 \\
Shuttle run 4× 10 m (s) & 10.42 & 0.39 & & 10.72 & 0.53 \\
Standing long jump (cm) & 188.49 & 13.91 & & 186.00 & 14.51 \\
Hexajump (cm) & 11.88 & 0.79 & & 11.73 & 0.66 \\
Throw a 2 kg medicine ball (m) & 6.44 & 0.96 & & 6.25 & 1.05 \\
Sit-ups - 2 minutes (n) & 73.71 & 14.95 & & 73.03 & 15.09 \\
Pull-ups with upper grip (n) & 4.06 & 3.25 & & - & - \\
30 m cursory run (s) & 4.32 & 0.26 & & 4.40 & 0.28 \\
\hline
\end{tabular}

Table 3

The results of the athletic polyathlon (final tests) of boys and girls - grade 9

\begin{tabular}{|c|c|c|c|c|}
\hline \multirow[b]{2}{*}{ Test } & \multicolumn{2}{|c|}{ Boys } & \multicolumn{2}{|c|}{ Girls } \\
\hline & $M$ & $S D$ & $M$ & $S D$ \\
\hline Run for 60 m (s) & 8.36 & 0.49 & 8.74 & 0.40 \\
\hline Run for 1500 m (s) & 344.61 & 36.75 & 370.46 & 27.91 \\
\hline Long jump (m) & 4.73 & 0.54 & 4.33 & 0.32 \\
\hline Shot-put (m) & 9.09 & 1.71 & 7.95 & 1.50 \\
\hline Athletic polyathlon (T-score) & 200 & 30.02 & 200 & 26.54 \\
\hline
\end{tabular}

Table 4

Prediction validity - the evaluation of entry tests with regard to the overall criteria - point results in the athletic polyathlon (time difference of 4 years)

\begin{tabular}{lll}
\hline & \multicolumn{2}{c}{$\mathrm{r}_{\mathrm{p}}$-correlation } \\
\cline { 2 - 3 } Tests of entry test battery & \multicolumn{1}{c}{ Boys } & Girls \\
\hline Run for 12 minutes (m) & $+.367^{* *}$ & $+.297^{*}$ \\
Shuttle run 4x10 m (s) & $-.357^{* *}$ & $-.447^{* *}$ \\
Standing long jump (cm) & $+.476^{* *}$ & $+.607^{* *}$ \\
Hexajump (cm) & $+.415^{* *}$ & $+.543^{* *}$ \\
Throw a 2 kg medicine ball (m) & $+.485^{* *}$ & $+.399^{* *}$ \\
Sit-ups - 2 minutes (n) & +.178 & $+.292^{*}$ \\
Pull-ups with upper grip (n) & $+.273^{* *}$ & - \\
30 m cursory run (s) & $-.490^{* *}$ & $-.763^{* *}$ \\
Total of T-score (8 entry tests) & $+.585^{* *}$ & $+.681^{* *}$ \\
\hline
\end{tabular}

${ }^{*} p \leq .05,{ }^{* *} p \leq .01$ 
Table 5

Entry tests predicting performance in the athletic polyathlon

\begin{tabular}{|c|c|c|c|}
\hline Variable in equation & $n$ & $R$ & $95 \% \mathrm{CI}$ \\
\hline \multicolumn{4}{|l|}{ Boys } \\
\hline 30 m cursory run & 109 & $-.302 * *$ & {$[-54.48,-16.43]$} \\
\hline Throw a medicine ball & 109 & $.360 * *$ & {$[6.35,16.17]$} \\
\hline Run 12 minutes & 109 & $.259^{*}$ & {$[0.015,0.060]$} \\
\hline \multicolumn{4}{|l|}{ Girls } \\
\hline 30 m cursory run & 67 & $-.650 * *$ & {$[-95.99,-56.34]$} \\
\hline Hexajump & 67 & $.247 *$ & {$[2.73,14.65]$} \\
\hline
\end{tabular}

The number and type of predictors for boys changes according to the selected criteria (Table 6), which could be either any one of the athletic tasks to be performed or the result of the athletic polyathlon. Considering the results stated in the Table 6 , athletic performance can be predicted using just two or three tests instead of the original eight tests included in the test battery. No significant differences were found between the identified multiple correlation coefficient $R$, criterion vs. necessary predictors and criterion vs. all predictors.

The prediction validity of the total score of entry tests in relation to performance in the athletic polyathlon among girls was $r=.681(p<.01)$ (Table 4). The individual items in the test battery correlate with the results of the athletic polyathlon. The most significant association with the overall result of the athletic polyathlon is found with the standing long-jump and the hexajump (positive association) and the $30 \mathrm{~m}$ cursory run (negative association).

The future performance of girls can be predicted using the following tests (Table 5): $30 \mathrm{~m}$ cursory run and hexajump.

Given the results provided in Table 6, prospective athletic performance among girls can be predicted using just two tests instead of the seven tests included in the original test battery. No significant differences were found in girls among the identified multiple correlation coefficient $R$, criterion vs. necessary predictors and criterion vs. all predictors.

\section{Discussion}

The aim of this study was to analyse the battery of motor tests used to identify athletic talents and to suggest a simplified test battery while preserving the overall quality of the identification process.
The primary aim of talent selection is usually to identify whether or not children meet the basic requirements of a sport. We evaluated physical abilities such as endurance, speed, strength, flexibility and accuracy (Falk et al., 2004). The advantage of identifying athletic talents early on is that physical tests administered early in the talent detection process allow the requirements placed on the performer to be easily seen (Falk et al., 2004; Lidor, Arnon, \& Cohen, 2005). We can use the retrospective approach when carrying out research on talent detection (Lidor \& Lavyan, 2002), which may enable us to determine what steps need to be taken in the early years of exposure in order to develop talent. This research focused on an attempt to simplify the entry testing to which young talents are exposed, however, particularly with regard to the results of the athletic polyathlon, which was re-administered four years after the students' entry testing.

The predictive validity analysis presented as part of this research examined whether the results garnered would accurately predict future outcomes (Ruiz, 2009). We are here concerned with how well the results of motor tests predict future performance in the athletic polyathlon. Overall, we can conclude that the level of predictive validity of individual tests included in the test battery in relation to the set criterion is higher among the sample of girls (.29-.73) than it is among the sample of boys (.18-.49). The strongest association between the results of the athletic polyathlon among both boys and girls was found in the $30 \mathrm{~m}$ cursory run test ( $r=-.49$ and $r=-.73$, respectively). The predictive validity of entry tests in relation to the criterion of athletic performance in the polyathlon ranged from .59-.68; again, we found a stronger correlation among girls, although it must be noted that the battery of entry tests includes a lower number of tests (7) for girls than it does for boys (8). A comparison with other studies concerned with testing motor fitness and performance 
Table 6

The review of key predictors of given criteria

\begin{tabular}{|c|c|c|c|c|}
\hline \multirow{2}{*}{$\begin{array}{l}\text { Criterion } \\
\text { (Athletic test) }\end{array}$} & \multirow{2}{*}{$\begin{array}{l}\text { Predictors } \\
\text { (Necessary predictors of performance) }\end{array}$} & \multicolumn{2}{|c|}{ Multiple correlation $R$ criterion vs. } & \multirow[b]{2}{*}{$p^{\mathrm{b}}$} \\
\hline & & Necessary predictors & All predictors ${ }^{\mathrm{a}}$ & \\
\hline \multicolumn{5}{|l|}{ Boys } \\
\hline Athletic polyathlon & $\begin{array}{l}30 \text { m cursory run } \\
\text { Run } 12 \text { minutes } \\
\text { Throw a } 2 \mathrm{~kg} \text { medicine ball }\end{array}$ & .646 & .664 & .819 \\
\hline Run $60 \mathrm{~m}$ & $\begin{array}{l}30 \text { m cursory run } \\
\text { Throw a } 2 \mathrm{~kg} \text { medicine ball }\end{array}$ & .551 & .583 & .732 \\
\hline Run $1500 \mathrm{~m}$ & $\begin{array}{l}\text { Run } 12 \text { minutes } \\
\text { Sit-ups } \\
4 \times 10 \text { m shuttle run }\end{array}$ & .696 & .702 & .932 \\
\hline Long jump & $\begin{array}{l}30 \text { m cursory run } \\
\text { Throw a } 2 \mathrm{~kg} \text { medicine ball } \\
\text { Standing long jump }\end{array}$ & .616 & .646 & .717 \\
\hline Shot-put & $\begin{array}{l}\text { Throw a } 2 \mathrm{~kg} \text { medicine ball } \\
\text { Standing long jump }\end{array}$ & .580 & .620 & .649 \\
\hline \multicolumn{5}{|l|}{ Girls } \\
\hline Athletic polyathlon & $\begin{array}{l}30 \text { m cursory run } \\
\text { Hexajump }\end{array}$ & .794 & .801 & .914 \\
\hline Run $60 \mathrm{~m}$ & $\begin{array}{l}30 \mathrm{~m} \text { cursory run } \\
\text { Throw a } 2 \mathrm{~kg} \text { medicine ball }\end{array}$ & .741 & .766 & .744 \\
\hline Run $1500 \mathrm{~m}$ & $\begin{array}{l}\text { Run } 12 \text { minutes } \\
\text { Standing long jump }\end{array}$ & .643 & .648 & .961 \\
\hline Long jump & $\begin{array}{l}30 \text { m cursory run } \\
\text { Hexajump }\end{array}$ & .580 & .611 & .786 \\
\hline Shot-put & $\begin{array}{l}\text { Throw a } 2 \mathrm{~kg} \text { medicine ball } \\
30 \mathrm{~m} \text { cursory run }\end{array}$ & .403 & .519 & .405 \\
\hline
\end{tabular}

Note. $\quad{ }^{\text {a }} 8$ item test battery for boys, 7 item test battery for girls. ${ }^{\text {b }}$ test of differences between two correlation coefficients.

in athletics is difficult due to a lack of relevant studies (Ruiz et al., 2011).

In the analysis of the battery of motor tests aimed at identifying sport talents in athletic sport classes, no significant differences were found between the predictive validity of the original battery of eight tests and the newly developed batteries containing just two and three tests for girls and boys, respectively.

Among the reduced number of test items, there needs to be a test which assesses maximum running speed (the best being the $30 \mathrm{~m}$ cursory run test) and a test assessing the power and strength of the lower limbs (either the hexajump or standing long-jump). In order to identify talents in sports such as handball, important parameters such as running speed and agility are similarly evaluated. Research analysing handball players has shown that elite players score significantly better on tests which evaluate strength, speed, agility and cardio-respiratory endurance (Mohamed et al., 2009). The best predictors for the identification and development of rugby talents were similarly established using stepwise discrimination analyses, which also highlighted variables such as sprint time and static and dynamic strength (Pienaar, Spamer, \& Steyn, 1998).

Among the sample of boys, it is important to also administer either the run for 12 minutes or the $2 \mathrm{~kg}$ medicine ball throwing test. When selecting children for specific groups of athletic disciplines (sprinters, jumpers, shot-putters, etc.), there must always be a test included in the battery which can be used to estimate the key motor ability for the given set of athletic disciplines e.g., for running middle and long-distance track events, the run for 12 minutes test would be optimal.

Despite the difficulties associated with talent identification, the standard of proficiency varies between physical education classes (Matsudo, Rivet, \& Pereira, 1987). In the education programmes at elementary schools in the Czech Republic there are sport classes which work in cooperation with sporting clubs to identify and train potentially successful athletes.

When identifying sports talents and sorting them into sport classes at schools, more modern methods are available e.g. those which estimate muscle fibre type composition by measuring variables such as the 
content of dipeptides such as carnosine present in muscle fibres. There is still the need to be able to distinguish between, for instance, different track running distances (Baguet et al., 2011). As such, the emphasis is still on motor tests. It is clear that the motor tests are not the only necessary element in the process of identifying talented youths. In praxis, the identification and selection process of talents in different sports should apply a multivariate approach (Reilly, Williams, Nevill, $\&$ Franks, 2000). The original predictors of success nevertheless can be influenced by growth, exercise and coaching (Regnier, Salmela, \& Russell, 1993).

\section{Strengths and limitations}

A great advantage of this study is to be found with the fact that it is longitudinal in nature. Long-term or longitudinal studies are necessary if we are to determine which variables are important in predicting a sporting career (Nieuwenhuis, Spamer, \& van Rossum, 2002). Monitoring pupils in sport classes at a selected school also provided all participants with identical conditions and all were subject to the same approach from teachers and trainers working at the school. A further strength of the study is the application of objective methods in favour of the subjective evaluation of participants. On the other hand, the primary limitation of the study is that the school was not selected randomly which, due to the focus of the study, was not possible. With respect to an insufficient number of similar studies it is impossible to compare samples of children of a similar age range and test range. Regarding the absence of a random selection of athletic sports classes this model cannot be generalised, it would be desirable to perform further research on a larger sample of sports population.

\section{Conclusions}

The identification of talents is a necessary and valid tool which allows for the efficient prediction of prospective sports talents. The prediction validity of present entry tests in relation to performance in the athletic polyathlon ranges between .585-.681. The regression analysis shows that, in order to accurately predict future athletic performance, in the case of girls the $30 \mathrm{~m}$ cursory run and hexajump tests are sufficient, and for boys, the $30 \mathrm{~m}$ cursory run, throw a $2 \mathrm{~kg}$ medicine ball and run for 12 minutes tests are enough.

Further research should aim to include a larger sample of the population. Alternative batteries of tests should be analysed, and particularly those usually used in identifying talents in other sports disciplines. This analysis has served to clarify the required content of test batteries in relation to the aims of the identification and selection process, and has thus served also to increase the efficiency of the process as a whole.

\section{Acknowledgment}

The study has been supported by the research grant from the Ministry of Education, Youth and Sports of the Czech Republic (No. MSM 6198959221) "Physical Activity and Inactivity of the Inhabitants of the Czech Republic in the Context of Behavioral Changes”.

\section{References}

Baguet, A., Everaert, I., Hespel, P., Petrovic, M., Achten, E., \& Derave, W. (2011). A new method for non-invasive estimation of human muscle fiber type composition. PLoS ONE, 6(7), 1-6.

Baker, J. J., Cobley, S., \& Schorer, J. (2011). Talent identification and development in sport: International perspectives. New York, NY: Routledge.

Blahuš, P. (1991). On the prediction of talent in sport games. Acta Universitatis Carolinae. Gymnica, 28, 13-17.

Brown, J. (2001). Sports talent. Champaign, IL: Human Kinetics.

Bunc, V. (2004). Současné pohledy na identifikaci sportovního talentu (na př́kladu biatlonu a fotbalu) [Contemporary views on the sport talent identification (example of biathlon and soccer)]. In Identifikace pohybových talentü: sborník z mezinárodní konference (pp. 19-24). Praha: Univerzita Karlova v Praze.

Dovalil, J. (2009). Výkon a trénink ve sportu [The performance and training in sport]. Praha: Olympia.

Falk, B., Lidor, R., Lander, Y., \& Lang, B. (2004). Talent identification and early development of elite water-polo players: A 2 year follow-up study. Journal of Sports Sciences, 22, 347-355.

Grosser, M. (1991). Schnelligkeitstraining [Quickness workout]. München: BLV Verlagsgesellschaft.

Hebák, P., \& Hustopecký, J. (1987). Vicerozměrné statistické metody s aplikacemi [Multidimensional statistical methods with applications]. Praha: SNTL/Alfa.

Kutlu, M., Yapıcı, H., Yoncalık, O., \& Çelik, S. (2012). Comparison of a new test for agility and skill in soccer with other agility tests. Journal of Human Kinetics, 33, 143-150.

Lidor, R., Arnon, M., \& Cohen, Y. (2005). Measurement of talent in team handball: The questionable use of motor and physical tests. Journal of Strength and Conditioning Research, 19, 318-325.

Lidor, R., \& Lavyan, N. Z. (2002). A retrospective picture of early sport experiences among elite and near-elite Israeli athletes: Developmental and psychological perspectives. International Journal of Sport Psychology, 33, 269-289.

Loužecký, J. (1990). Konstrukce pravděpodobnostního modelu individuálního výkonu vybraných sportovců ve vztahu $k$ jejich vnitřnimu stavu [Construction of probability model of individual achievement of sampled athletes with regard to their 
internal state] (Doctoral dissertation). Charles University, Faculty of Physical Education and Sport, Prague.

Matsudo, V. K. R., Rivet, R. E., \& Pereira, M. H. N. (1987). Standard score assessment on physique and performance of Brazilian athletes in a six tiered competitive sports model. Journal of Sports Sciences, 5, 49-53.

Měkota, K. (1985). Problémy motorického vývoje v ontogenezi člověka $\mathrm{z}$ hlediska antropomotoriky [Problems of motor development in terms of human ontogeny anthropomotorics]. In K. Měkota (Ed.), Ontogeneze lidské motoriky (pp. 7-19). Praha: Olympia.

Mohamed, H., Vaeyens, R., Matthys, S., Multael, M., Lefevre, J., Lenoir, M., \& Philppaerts, R. (2009). Anthropometric and performance measures for the development of a talent detection and identification model in youth handball. Journal of Sports Sciences, 27, 257-266.

Nieuwenhuis, C. F., Spamer, E. J., \& van Rossum, J. H. A. (2002). Prediction function for identifying talent in 14 to 15 year old female field hockey players. High Ability Studies, 13, 21-33.

Perič, T. (2006). Výběr sportovních talentů [Selection of sport talents]. Praha: Grada.

Perič, T. (2008). K možnostem identifikace struktury sportovní talentovanosti [Possibilities of identification of structure of sport talent]. Praha: Karolinum.

Pienaar, A. E., Spamer, M. J., \& Steyn, H. S. (1998). Identifying and developing rugby talent among 10 year old boys: A practical model. Journal of Sports Sciences, 16, 691-699.
Regnier, G., Salmela, J., \& Russell, S. J. (1993). Talent detection and development in sport. In R. N. Singer, M. Murphey, \& L. K. Tennant (Eds.), Handbook of research on sport psychology (pp. 290-313). New York, NY: Macmillan.

Reilly, T., Williams, A. M., Nevill, A., \& Franks, A. (2000). A multidisciplinary approach to talent identification in soccer. Journal of Sports Sciences, 18, 695-702.

Ruiz, J. R. (2009). Predictive validity of health-related fitness in youth: A systematic review. British Journal of Sports Medicine, 43, 909-923.

Ruiz, J. R., Castro-Piñero, J., España-Romero, V., Artero, E. G., Ortega, F. B., Cuenca, M. M., ... Castillo, M. J. (2011). Field-based fitness assessment in young people: The ALPHA health-related fitness test battery for children and adolescents. British Journal of Sports Medicine, 45, 518-524.

Sultana, D., \& Manohar Chendur Pandi, J. (2013). Prediction of athletic ability from talent identification model on school students. In 3rd International Conference on Management, Economics and Social Sciences (ICMESS'2013) (pp. 118-121). Kuala Lumpur (Malaysia).

Vaeyens, R., Lenoir, M., Williams, A. M., \& Philippaerts, R. M. (2008). Talent identification and development programmes in sport: Current models and future directions. Sports Medicine, 38, 703-714.

Vala, R., Valová, M., Litschmannová, M., \& Klimtová, H. (2010). Sprinting abilities of year six students undergoing additional physical education classes. The New Educational Review, 22, 165-178. 